\title{
The Manuscripts of the Scholia to the Hesiodic Aspis
}

\section{Pediasimus'Scholia Paraphrastica}

\author{
Konstantine Panegyres \\ Trinity College, Oxford \\ konstantine.panegyres@classics.ox.ac.uk \\ Received September 2019 | Accepted September 2019
}

\begin{abstract}
This paper presents a collation and investigation of some manuscripts of Ioannes Pediasimus' scholia paraphrastica to the Hesiodic Aspis. The paper demonstrates that the editions currently used by scholars are based on an insecure textual foundation.
\end{abstract}

\section{Keywords}

Hesiod - The Shield of Herakles - scholia - Byzantine scholarship

1

The scholia to the Hesiodic Aspis have not received much attention from modern scholars. The scholia vetera were last published by Ranke in $1840 .^{1}$ Some substantial efforts have been made to assess the textual history of this material more fully, ${ }^{2}$ but there is still a need for further study in this area. A separate group of scholia has fared much less well. Ioannes Pediasimus (c.1240-c.1310 $)^{3}$ wrote two sets of scholia on the Aspis: a set of paraphrastic scho-

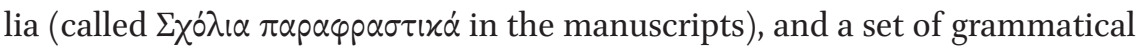

1 Ranke 1840.

2 Schultz 1910; Martano 2002, 2005, 2006, and 2008.

3 PLP no. 22235; Wilson 1996, 242-243; Levrie 2018, 1-10. 


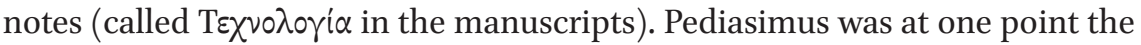
leading professor at Constantinople and held the post of $\tilde{\pi} \pi \alpha \tau \sigma \tau \hat{\omega} \nu \varphi$ and so his scholia are important for an understanding of how the Hesiodic Aspis was read and understood by major scholars in the Palaeologan age. The scholia of Pediasimus were last published by Gaisford in $1823,{ }^{4}$ and since then no study has been made of them save for the publication of a handful of emendations. ${ }^{5}$ Unfortunately, in the available editions of the text these separate scholia are conflated and printed together, so that it can be difficult for a reader to tell exactly where the scholia paraphrastica end and the technologia begins. In fact, these works were clearly demarcated in the manuscripts by different titles, and should be treated as distinct pieces of scholarship. The present article deals only with the manuscripts of Pediasimus' scholia paraphrastica. The aim is to place understanding of this work on a more secure textual foundation by providing information about the readings of the manuscripts.

2

The number of manuscripts known to me, in which Pediasimus' scholia paraphrastica can be found, is nine.

T Marcianus gr. Z. 464, fourteenth century.

M Marcianus gr. Z. 48o, fifteenth century.

V Vindobonensis Phil. gr. 25, fifteenth/sixteenth century.

G Monacensis Cod. graec. 283, fifteenth/sixteenth century.

B Vaticanus Barb. gr. 98, sixteenth century.

H Harvardensis Houghton MS. gr. 20, sixteenth century. Olomucensis M 79, fifteenth century (excerpts only). Laurentianus Plut. 31.24, fifteenth century (excerpts only). Matritensis 4607, fifteenth century (paraphrase only).

Scholars of the scholia to the Hesiodic Aspis have previously known of the existence of Pediasimus' scholia paraphrastica in most of these manuscripts. In his catalogue, Schultz mentioned the presence of the text in T, M, G, V, and Laurentianus $31.24 .{ }^{6}$ Later, Corralez Pérez added Matritensis 4607 as a

4 Gaisford 1823, 6o9-654.

5 Mason 2015. The Pediasimus scholia are very briefly introduced in Russo 1965, 56.

6 Schultz 1910, 8, 16, 29-31. 
witness. ${ }^{7}$ For the preparation of the editio princeps of 1537 , Trincavelli used $\mathrm{T}$ and $\mathrm{M}$; later editors (Heinsius, Heinrichius, and Gaisford) do not mention manuscripts. The text of the scholia paraphrastica in these manuscripts has not been examined in modern times. ${ }^{8}$ Gaisford's Leipzig edition is the one most commonly used and referred to by scholars: T. Gaisford, Poetae Minores Graeci, II, Leipzig 1823, 6o9-654. ${ }^{9}$ References to Pediasimus in this article will follow the page and line numbering of this edition.

The tradition of the scholia paraphrastica is comprised of complete manuscripts containing the entirety of the transmitted text on the one hand, and manuscripts containing short excerpts or paraphrases on the other.

All the manuscripts descend from an archetype which had an error at 619.8

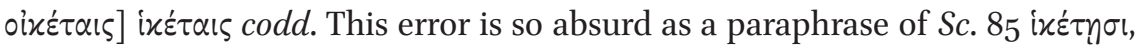
that one is compelled to postulate that it belongs to the common ancestor of all the manuscripts.

The manuscripts $\mathbf{T}, \mathbf{M}$, and $\mathbf{V}$ share a very similar text, with only a handful of variants distinguishing them from one another.

1. $\mathrm{T}$ = Venice, Biblioteca Nazionale Marciana, Marcianus gr. Z. 464 (= coll. 762 ), saec. XIV (dated to AD 1316-1319), written by Demetrius Triclinius. ${ }^{10}$ The manuscript belonged to Cardinal Bessarion. ${ }^{11}$ On ff. $2^{\mathrm{r}}-13^{\mathrm{r}}$ the scholia paraphrastica have been written into the margins next to the text of the Aspis. At

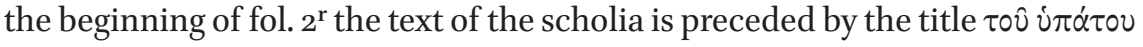

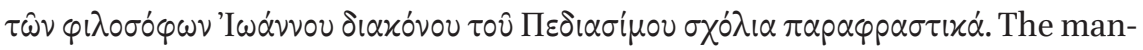
uscript was collated by me from high-quality colour images.

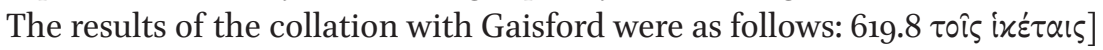

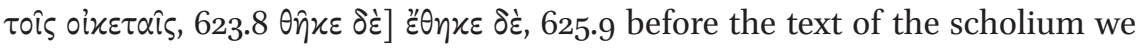

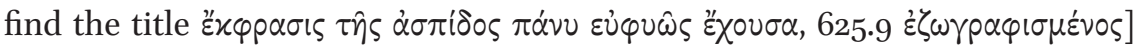

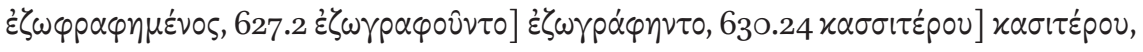

$7 \quad$ Corrales Pérez 1994, 41. For help with obtaining images of manuscripts I wish to thank Rostislav Krušinský (Olomouc), Ingeborg Formann and Hans Peter Zimmer (Vienna), Will Gregg (Harvard), Pierre Augustin (Institut de recherche et d'histoire des textes), and Alessandro Moro (Venice).

8 In his study of the manuscripts of Pediasimus, Domenico Bassi omitted to list any manuscripts of the scholia paraphrastica or technologia: see Bassi 1898, 1408.

$9 \quad$ The printing errors in this Leipzig edition (not present in the earlier Oxford edition) need

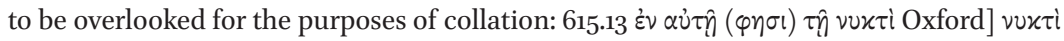

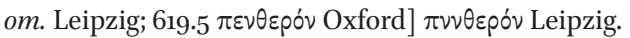

10 Mioni 1985, 248-251.

11 Id., 272-275. 


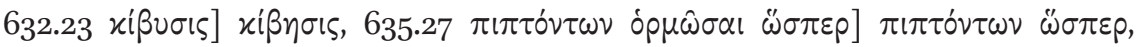

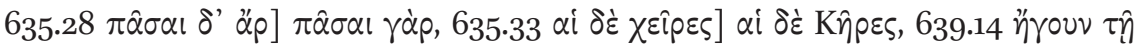

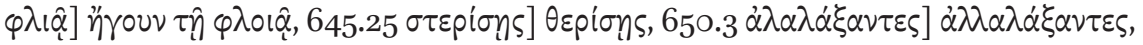

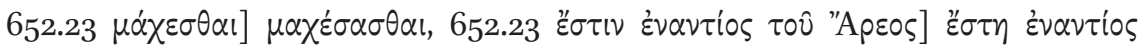

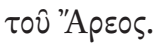

2. $\mathbf{M}=$ Venice, Biblioteca Nazionale Marciana, Marcianus gr. Z. 480 (= coll. 589), saec. XV (middle), written by Georgios Tribizias. The manuscript belonged to Cardinal Bessarion. ${ }^{12}$ On ff. $215^{\mathrm{r}}-225^{\mathrm{v}}$ the scholia paraphrastica have been written into the margins next to the text of the Aspis. At the beginning of fol. $215^{\mathrm{r}}$ the text of the scholia is preceded by the title $\tau 0 \hat{v} i \pi \alpha$ tov $\tau \hat{\omega} \nu$

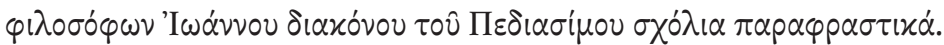

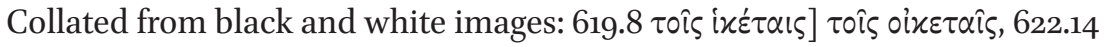

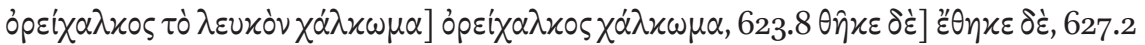

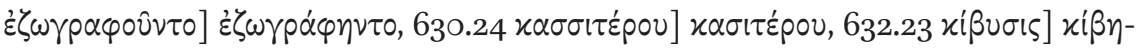

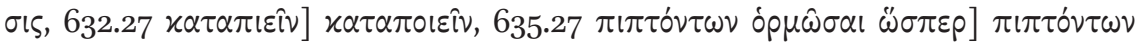

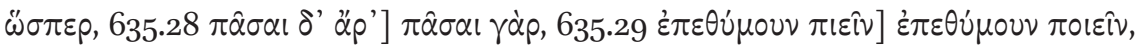

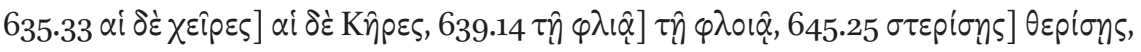

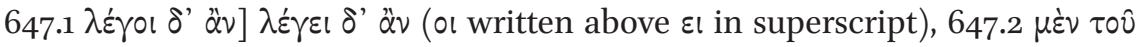

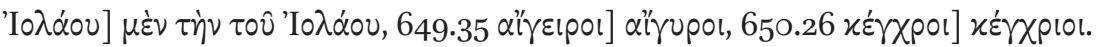

3. V = Vienna, Österreichische Nationalbibliothek, Phil. gr. 25, saec. XV according to Schultz, ${ }^{13}$ but now thought to be saec. XVI (first half); probably written by Aristoboulos Apostolis (Arsenius of Monembasia). ${ }^{14}$ The manuscript belonged to George, Count of Corinth. ${ }^{15}$ It was later purchased in Florence by Johannes Sambucus. ${ }^{16}$ The scholia paraphrastica are found at $\mathrm{ff} .81^{\mathrm{r}}-88^{\mathrm{r}}$. The

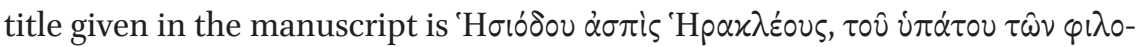

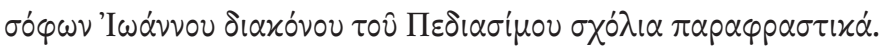

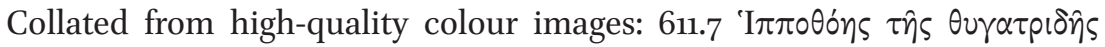

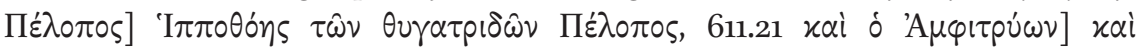

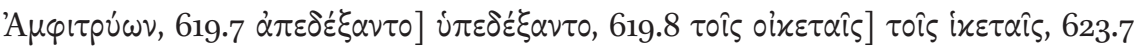

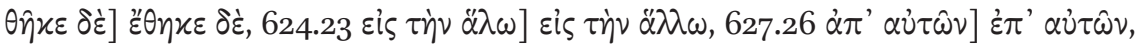

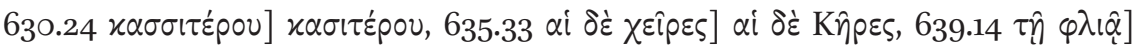

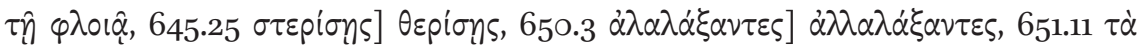

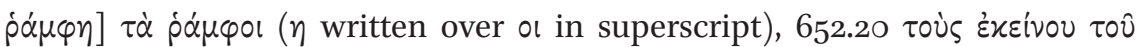

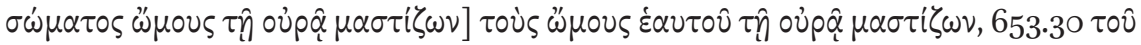

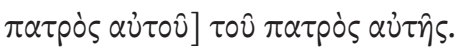

$\begin{array}{ll}12 & \text { Id., 272-275. } \\ 13 & \text { Schultz 1910, 31. } \\ 14 & \text { Hunger 1961, 154-156. } \\ 15 & \text { Pingree 1977, 359. } \\ 16 & \text { Hunger 1961, 156. }\end{array}$


The manuscripts $\mathbf{M}$ and $\mathbf{V}$ are both apographs of $\mathbf{T}$. In the few places where they diverge from the text of $\mathrm{T}$, their errors are trivial. Some examples: 622.14

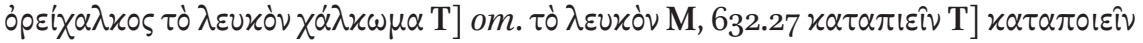

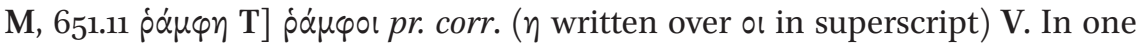

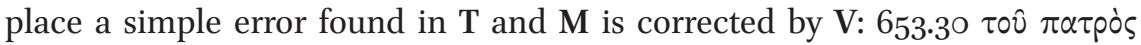

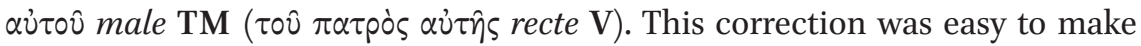

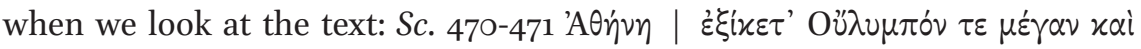

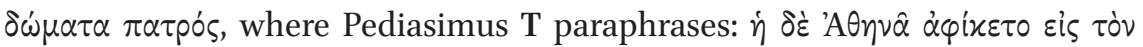

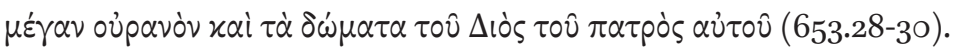

An important group of manuscripts is represented by some recentiores. These are the following:

4. $\mathbf{G}=$ Munich, Bayerische Staatsbibliothek, Cod. Monacensis graec. 283,

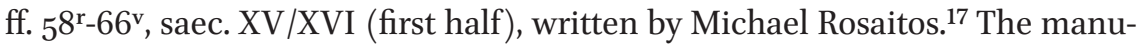
script belonged to Johann Albrecht Widmannstetter. Collated from black and white images.

5. B = Vatican, Biblioteca Apostolica Vaticana, Barb. gr. 98, ff. $12^{\mathrm{r}}-17^{\mathrm{r}}$, saec. XVI (beginning), copied in Otranto. ${ }^{18}$ The manuscript was owned by Girolamo Seripando and later by Giovanni Paolo Parrasio. In the margins there are many notes in Latin and some in Greek; parts of the Greek text have been corrected by a second hand. Collated from high-quality colour images.

6. $\mathrm{H}=$ Harvard University, The Houghton Library, MS gr. $20, \mathrm{ff} .127^{\mathrm{r}}-139^{\mathrm{r}}$, saec. XVI (c. 1520), copied in Otranto; the manuscript belonged to Joannes Baptista Rota. ${ }^{19}$ Collated from high-quality colour images.

The three manuscripts are related to one another, and were probably derived from a common exemplar, which I shall call $\mathbf{r}$. This is demonstrated by the following places where they agree in error against all other manuscripts. ${ }^{20}$

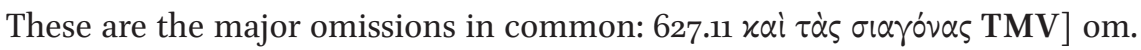

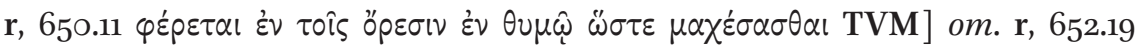

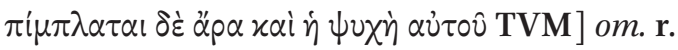

\footnotetext{
17 Hajdú and Schreiner 2013, 25-52, at 42-43.

18 Capocci 1958, n. 98; Vendruscolo 2005, 512-524, at 517; Formentin 2010, 401-408, at 406 n. 13; Ferreri 2002, 196-197, 199-203.

19 Kavrus-Hoffmann 2010, 207-274, at 232-238.

20 I do not include here variant late spellings, such as $611.19 \dot{\alpha} \varphi \alpha v_{i} \sigma \alpha \mathrm{l}$ TVM] $\dot{\alpha} \varphi \alpha v \hat{\eta} \sigma \alpha \iota \mathrm{r}$.
} 
There are also many smaller errors shared between them: 614.23 이v $\hat{\eta} \lambda \theta \varepsilon v$

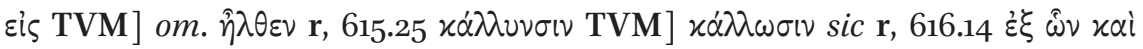

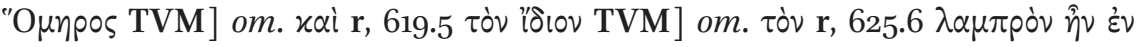

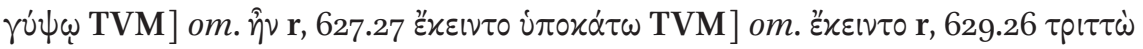

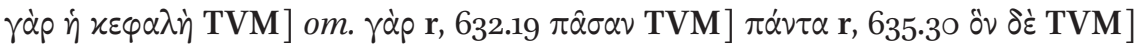

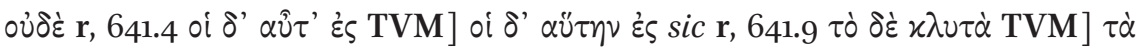

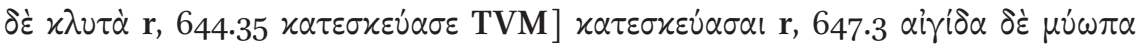

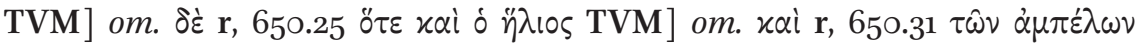

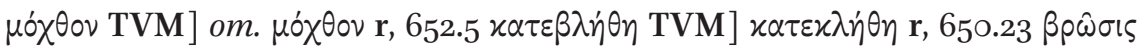

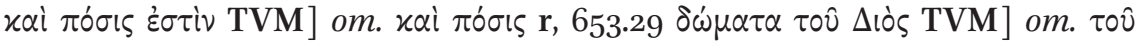
$\Delta$ iò $\mathbf{r}$. The manuscripts offer about a dozen variants, but none of them are certainly true.

When we look at the relations between $\mathbf{G}, \mathbf{B}$, and $\mathbf{H}$, it becomes apparent that no clear internal relations between these manuscripts will emerge. In

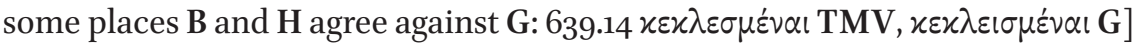

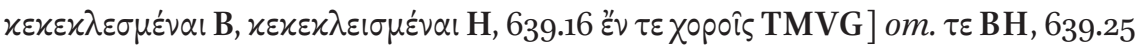

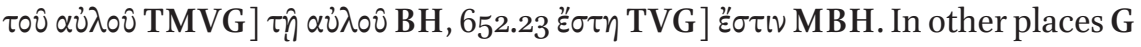

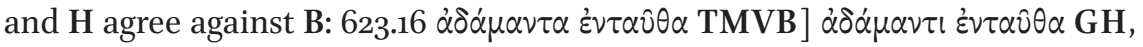

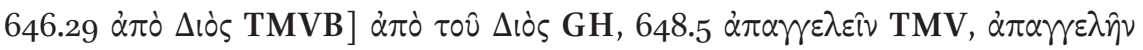

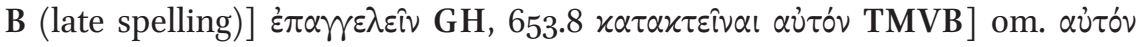

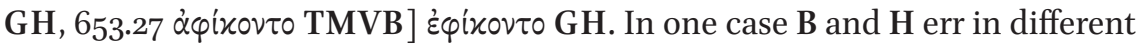
ways over the copying of a word transmitted correctly in G: 651.11 $\rho \alpha \mu \varphi \eta$ TMG]

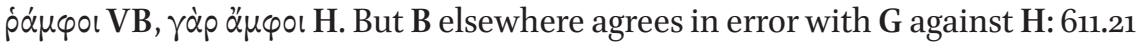

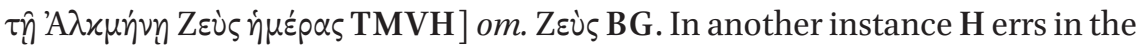

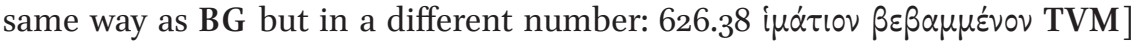

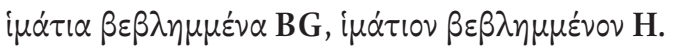

Each manuscript is descended from $\mathbf{r}$ but has many of its own unique errors, and also shares errors sometimes with one manuscript in the group and sometimes with another. Hence $\mathbf{B}$ sometimes shares errors with $\mathbf{H}$ against $\mathbf{G}$, but also sometimes shares errors with $\mathbf{G}$ against $\mathbf{H}$. An explanation for this is contamination. It will be difficult to determine the internal relations of these manuscripts without the discovery of other related manuscript witnesses descended from $\mathbf{r}$.

The least corrupt manuscript in this group is $\mathbf{G}$, which is also the earliest manuscript in the group. It has unique variants in the following places: 617.3

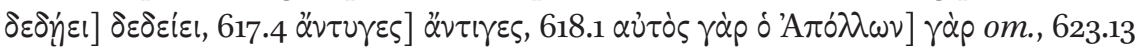

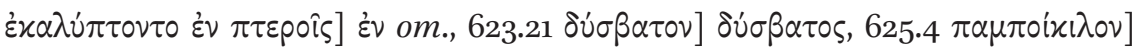

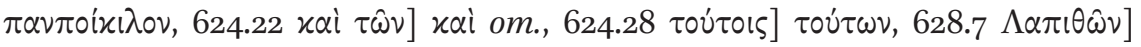

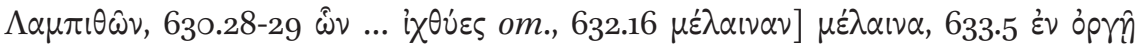




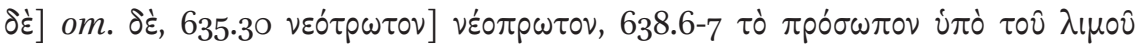

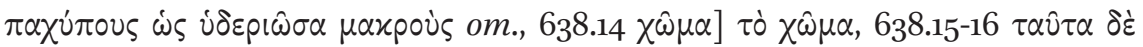

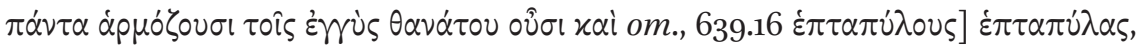

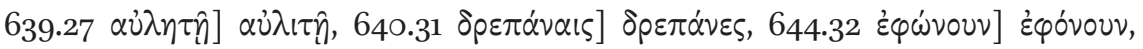

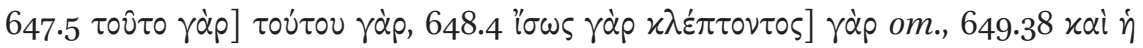

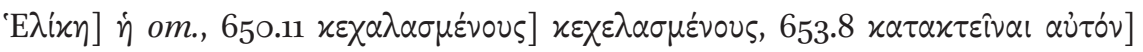
aủióv om.

The character of B's text is demonstrated by the following errors: ${ }^{21} 611.3$

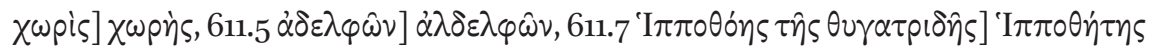

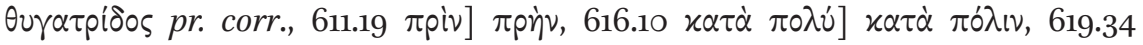

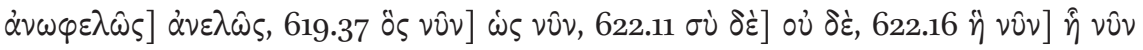

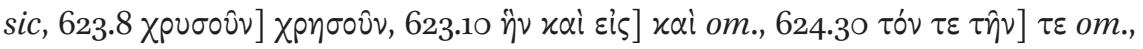

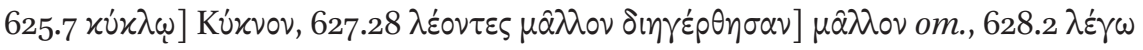

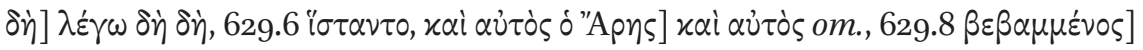

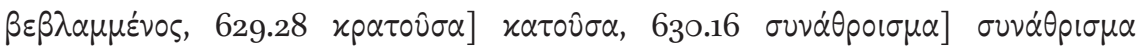

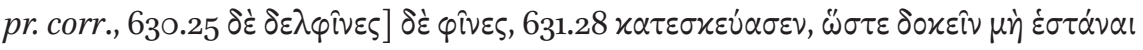

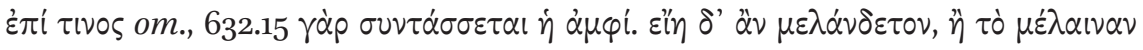

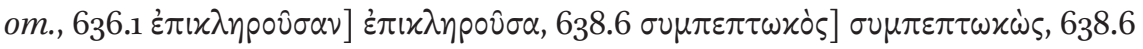

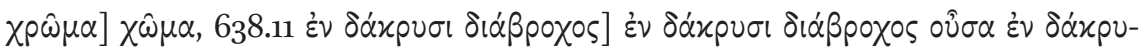

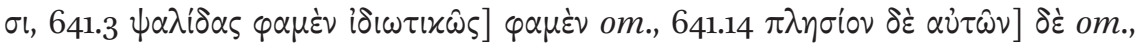

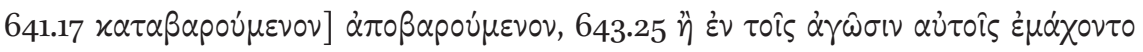

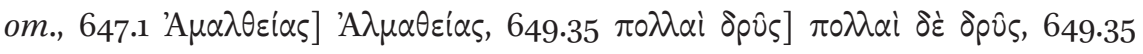

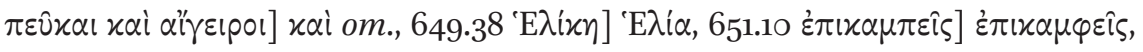

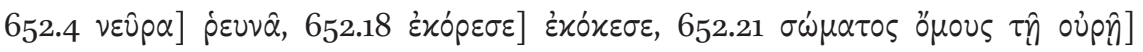
örous om.

$\mathrm{H}$ has the most errors among these manuscripts. Reported here are only some samples, selected from the beginning (61o-611), middle $(625,627,639)$,

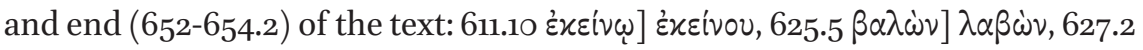

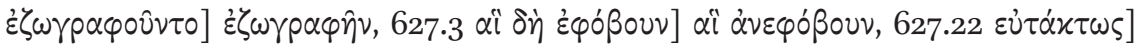

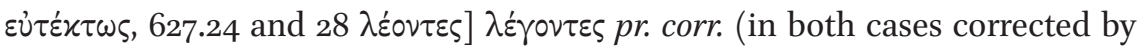

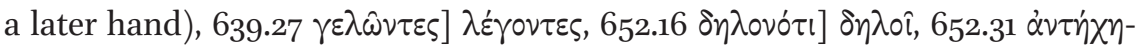

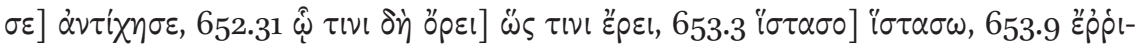

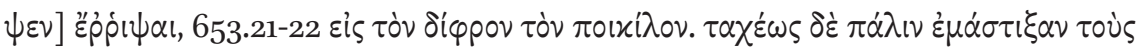

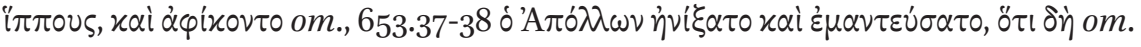

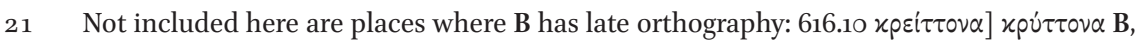

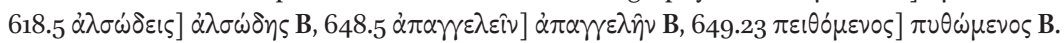


The next three manuscripts of the fifteenth century offer an abridged form of the text. They have proved to be textually unhelpful. Sigla have not been accorded to them.

7. Olomouc, Státní Vědecká Knihovna, Olomucensis M 79, saec. XV (middle), written by Demetrius Trivolis. ${ }^{22}$ Collated from high-quality colour images. On ff. $\mathrm{1}^{\mathrm{r}}-9^{\mathrm{v}}$ the scholia paraphrastica have been written into the margins next to the text of the Aspis. There is no title. The manuscript only contains minor excerpts from Pediasimus' scholia paraphrastica, rather than the complete work, so we are not given a full picture of the text available to its copyist. The manuscript does not contain enough material to establish its affinities with

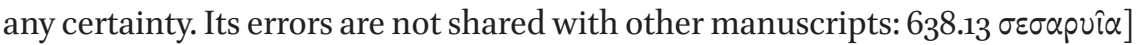

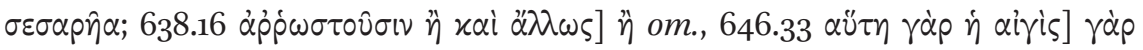

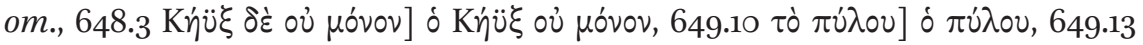

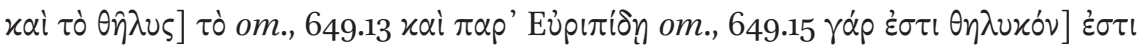
om. After 649.15 this manuscript has a small addition to the scholion based

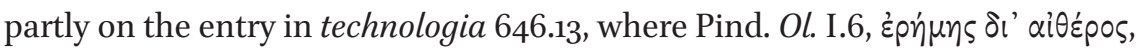
is quoted. ${ }^{23}$

8. Madrid, Biblioteca Nacional, Matritensis 46o7, saec. XV (1458-1465), written by Konstantinos Lascaris. ${ }^{24}$ Collated from colour images. On ff. $51^{\mathrm{v}}-53^{\mathrm{v}}$ the scholia have been presented as a single body of text, rather than in the mar-

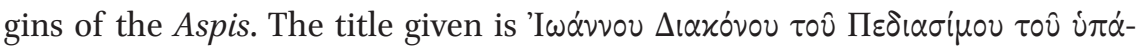

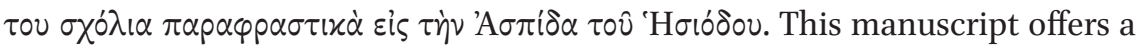
paraphrase of the contents of Pediasimus' scholia paraphrastica.

Here are two examples displaying the character of the paraphrase. At 628.1-2,

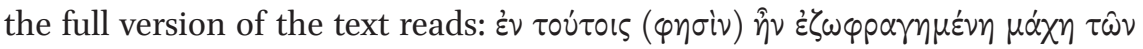

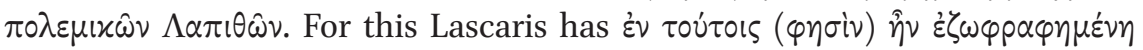

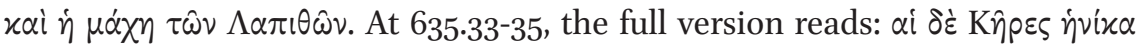

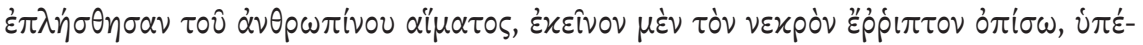

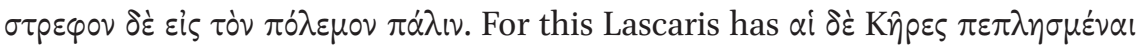

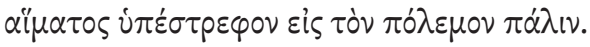

Lascaris was fond of paraphrase and abbreviation. Elsewhere in this same manuscript there is an anonymous paraphrase of the Aspis (from f. 121), ${ }^{25}$

22 Olivier and Monégier du Sorbier 1983, 22-23; for support of Gamillscheg's identification of the scribe as Demetrius Trivolis, see further Wilson 1985, 175 .

23 Noted already in Olivier and Monégier du Sorbier 1983, 176.

24 Iriarte 1769, 24-27; Schultz 1910, 11; Vogel and Gardthausen 1909, 244.

25 Iriarte $1769,25$. 
which I have not been able to examine. There is also an abbreviated version of Pediasimus' technologia in Matr. 4629, ff. $68^{\mathrm{v}}-69^{\mathrm{v}}$, and, according to Corrales Pérez, Lascaris used this to annotate his text of the Aspis. ${ }^{26}$ Corrales Pérez reported that in the margins of the text of the Aspis in Matr. 4607 a few mythological scholia can be found, and that these have been adapted from Pediasimus' scholia paraphrastica. ${ }^{27}$ I have not been able to check the text of these.

9. Florence, Biblioteca Medicea Laurenziana, Laur. Plut. 31.24, saec. XV (perhaps 1480s), written by George Hermonymus. ${ }^{28}$ The manuscript belonged to Piero de' Medici, to whom it was given by his father, Lorenzo. Collated from high-quality colour images. On ff. $142^{r}-143^{r}$ there is a small selected excerpt

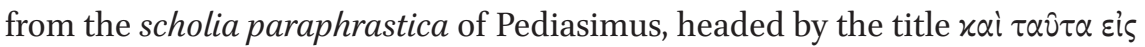

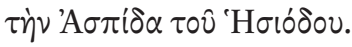

This has the text of the scholia paraphrastica from 610.36 to 624.33. Here are

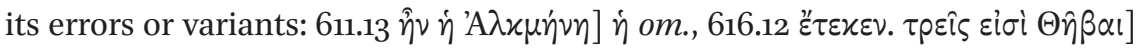

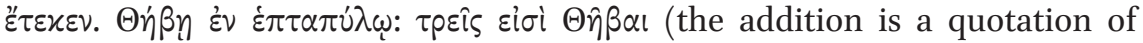

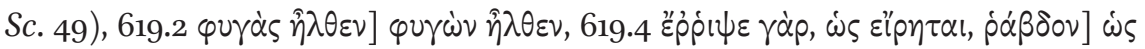

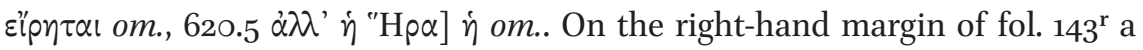

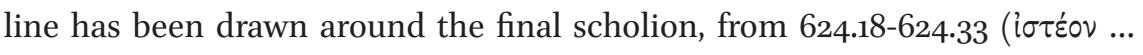
$\varkappa \alpha \tau \alpha \sigma \varkappa \varepsilon \cup \eta \dot{)}$ ), and the word $\dot{\eta} \mu \varepsilon \dot{\tau \varepsilon p o v}$ has been added as a note.

\section{6}

I now turn to the editions of the text. This particular set of scholia has been edited five times:

V. Trincavellus, Hesiodi Ascraei Opera et Dies, Theogonia, Scutum Herculis. Omnia vero cum multis optimisque expositionibus, Venice 1537, fol. clxix-lxxxviii.

D. Heinsius, Hesiodi Ascraei quae extant, Leiden 16o3, 187-224.

C.F. Heinrichius, Hesiodi Scutum Herculis, Breslau 1802, 6o-106.

T. Gaisford, Poetae Minores Graeci, III, Oxford 1820, 499-534.

T. Gaisford, Poetae Minores Graeci, II, Leipzig 1823, 6o9-654.

In 1537 Vettore Trincavelli published the editio princeps of the scholia paraphrastica of Pediasimus in the printing-house of Bartolomeo Zanetti.

$26 \quad$ Corrales Pérez 1994, 218.

27 Corrales Pérez 1994, 218, with a collated sample of the text.

28 Speranzi 2016, 79-80; Schultz 1910, 8. 
The manuscript basis of this edition was a combination of $\mathrm{T}$ and M. Trincavelli carries over the readings of $\mathbf{M}$ against those of $\mathbf{T}$ in the following

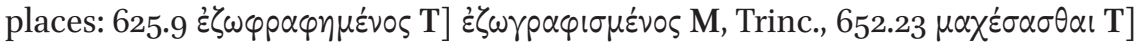

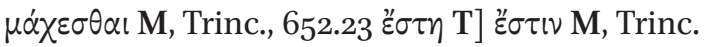

In orthographical matters, too, Trincavelli sides with $\mathbf{M}$ against T: 649.35

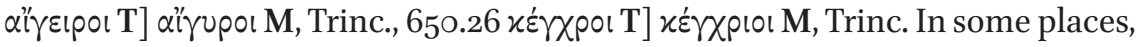
however, Trincavelli must have corrected $\mathbf{M}$ against $\mathrm{T}$, as the following exam-

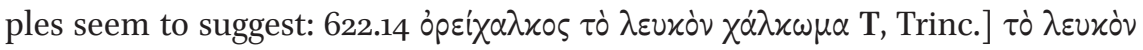

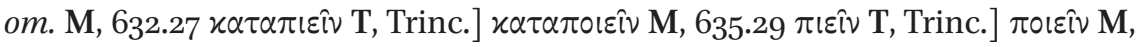

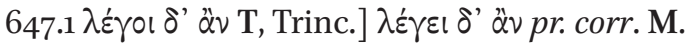

The most important error in Trincavelli's edition comes at 635.33, where the mistake has influenced all later editions (the lemma is the agreement of all the manuscripts):

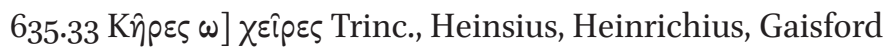

This common error suggests that Trincavelli's collation of the text was not checked against the manuscripts by any later editors.

In 1603 Heinsius published the scholia paraphrastica of Pediasimus as part of his edition of the text of Hesiod. Heinsius says nothing about the manuscript sources of his text. The significance of Heinsius' edition lies in the fact that he incorporated his own corrections in various places, and these in turn were integrated into the later editions of Heinrichius and Gaisford:

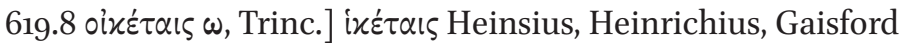 \\ 623.8 है $\theta \eta x \varepsilon \omega$, Trinc.] $\theta \hat{\eta} x \varepsilon$ Heinsius, Heinrichius, Gaisford

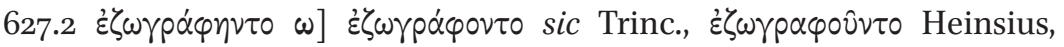 \\ Heinrichius, Gaisford

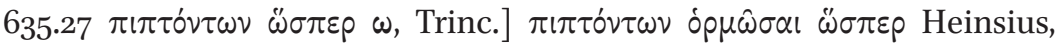 \\ Heinrichius, Gaisford

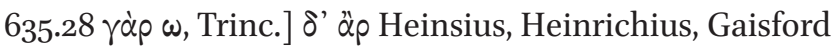 \\ $639.14 \varphi \lambda_{0} \mid \hat{\alpha} \omega \omega$, Trinc.] $\varphi \lambda ı \hat{\alpha}$ Heinsius, Heinrichius, Gaisford

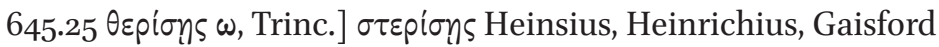 \\ $650.3 \alpha \lambda \lambda \alpha \lambda \dot{\alpha} \xi \alpha \nu \tau \varepsilon \varsigma \omega$, Trinc.] $\alpha \lambda \alpha \lambda \dot{\alpha} \xi \alpha \nu \tau \varepsilon \varsigma$ Heinsius, Heinrichius, Gaisford
}

Neither Heinrichius nor Gaisford used new manuscript material. Heinrichius mentioned no manuscripts at all. In the case of Gaisford, who dedicated his volume to Heinsius, none of the manuscripts listed in his index codicum contains the text of the scholia paraphrastica of Pediasimus. The editions of Heinrichius and Gaisford are therefore derivative of the work of Trincavellus and Heinsius. 
It is premature to offer broad conclusions about the transmission of Pediasimus' scholia paraphrastica before all of the manuscripts containing scholia to the Aspis have been thoroughly collated and investigated. No stemma can yet be drawn safely. The aim of this discussion has been to bring attention to the readings found in the manuscripts, not to provide a full history of the text. Since Pediasimus' scholia are in general poorly catalogued, versions of the scholia paraphrastica might still lie undetected in the margins of manuscripts of the Aspis not yet fully studied or accurately described. More discoveries are therefore to be expected.

\section{Bibliography}

Bassi, D. (1898). I manoscritti di Giovanni Pediasimo. Reale Istituto Lombardo di scienze e lettere, Rendiconti, ser. II, 31, pp. 1399-1418.

Capocci, V. (1958). Codices Barberiniani Graeci, Vol. I: Codices 1-163. Vatican City.

Corrales Pérez, Y. (1994). Die Überlieferungsgeschichte des pseudohesiodischen Scutum Herculis. Dissertation, Hamburg.

Ferreri, L. (2002). I codici parrasiani della Biblioteca Vaticana, con particolare riguardo al Barberiniano greco 194, appartenuto a Giano Lascaris. AION(filol) 24, pp. 189-223.

Formentin, M. (2010). Un nuovo codice di Giovanni Lido, autografo di Aulo Giano Parrasio. In: M. D'Agostino and P. Degni, eds., Alethes philia. Studi in onore di Giancarlo Prato, Vol. 2, Spoleto, pp. 401-408.

Gaisford, T. (1823). Poetae Minores Graeci, Vol. 2. Leipzig.

Hajdú, K., and Schreiner, P. (2013). Nikolaos von Otranto und ein angeblicher Plagiator im Cod. graec. 262 der Bayerischen Staatsbibliothek. Mit einem Anhang zur Provenienz der griechischen Handschriften aus der Sammlung Johann Albrecht Widmannstetters. Codices Manuscripti \& Impressi 87-88, pp. 25-52.

Hunger, H. (1961). Katalog der griechischen Handschriften der Österreichischen Nationalbibliothek, Vol. . Vienna.

Iriarte, J. (1769). Regiae Bibliothecae Matritensis Codices Graeci Manuscripti, Vol. 1. Madrid.

Kavrus-Hoffmann, N. (2010). Catalogue of Greek Medieval and Renaissance Manuscripts in the Collections of the United States of America, Part V.2: Harvard University, The Houghton Library. Manuscripta 54, pp. 207-274.

Levrie, K. (2018). Jean Pédiasimos. Essai sur les douze travaux d' Héracles. Édition critique, traduction et introduction. Leuven. 
Martano, A. (2002). Scolii e glosse allo Scudo di Eracle dal manoscritto Ambrosiano C 222 inf. Aevum 76, pp. 151-20o.

Martano, A. (2005). La tradizione manoscritta dell'esegesi antica allo Scudo di Eracle esiodeo. La famiglia del Vat. gr. 1332 (sec. XIII-XV). Aevum 79, pp. 461-489.

Martano, A. (2006). L'esegesi antica allo Scudo di Eracle nell'Etymologicum Genuinum e Gudianum. In: G. Avezzù and P. Scattolin, eds., I classici greci e i loro commentatori. Dai papiri ai marginalia rinascimentali. Atti del convegno, Rovereto, 20 ottobre 2006, Rovereto, pp. 85-119.

Martano, A. (2008). La tradizione manoscritta dell'esegesi antica allo Scudo di Eracle esiodeo. Due gruppi di codici (sec. XIV-XVI). Aevum 82, pp. 543-58o.

Mason, H.C. (2015). Pediasimus on the Hesiodic Shield of Heracles. RhM158, pp. 220-224.

Mioni, E. (1985). Bibliothecae Diui Marci Venetiarum Codices Graeci Manuscripti, Vol. 2: Thesaurus Antiquus. Codices 300-625. Rome.

Olivier, J.-M., and Monégier du Sorbier, M.-A. (1983). Catalogue des manuscrits grecs de Tchécoslovaquie. Paris.

Pingree, D. (1977). The Library of George, Count of Corinth. In: K. Treu, ed., Studia codicologica, Berlin, pp. 351-362.

Ranke, C.F. (1840). Hesiodi quod fertur Scutum Herculis. Quedlinburg/Leipzig.

Russo, C.F. (1965). Hesiodi Scutum. Florence.

Schultz, H. (1910). Die handschriftliche Überlieferung der Hesiod-Scholien. Berlin.

Speranzi, D. (2016). Omero, i cardinali e gli esuli. Copisti greci di un manoscritto di Stoccarda. Madrid.

Vendruscolo, F. (2005). Codici greci del Parrasio e di S. Giovanni a Carbonara nel fondo Barberini della Vaticana. Miscellanea Bibliothecae Apostolicae Vaticanae 12, pp. $512-524$

Vogel, M., and Gardthausen, V. (1909). Die griechischen Schreiber des Mittelalters und der Renaissance. Leipzig.

Wilson, N.G. (1985). [Review of Olivier and Monégier du Sorbier 1983]. CR 35, pp. 175-176.

Wilson, N.G. (1996). Scholars of Byzantium. London. 